\title{
The Influence of Carbon Coatings on the Functional Properties of X39Cr13 and 316LVM Steels Intended for Biomedical Applications
}

\author{
Roberto López ${ }^{1, *(1)}$, Marta Menéndez ${ }^{2}$, Camino Fernández ${ }^{3}$, A. Chmiela $^{4}$ and \\ Antonio Bernardo-Sánchez 2 (D) \\ 1 Department Area of Physical Chemistry, Faculty of Industrial Engineering, Universidad de León, \\ 24071 León, Spain \\ 2 Faculty of Mines, Universidad de León, 24071 León, Spain \\ 3 Chemical and Environmental Bioprocess Engineering Group, Institute of Natural Resources, Universidad de \\ León, 24071 León, Spain \\ 4 Faculty of Mining and Geology, Silesian University of Technology, 44-100 Gliwice, Poland \\ * Correspondence: rlopg@unileon.es; Tel.: +34-987-291-921
}

Received: 28 June 2019; Accepted: 23 July 2019; Published: 24 July 2019

check for updates

\begin{abstract}
Carbon coatings are used in many different industrial areas, for example in cutting, electronics, or medical applications. On the one hand, carbon coatings have improved the functional properties of medical products because of their high biotolerance, which makes them an important material for implant coatings. On the other hand, high rigidity and abrasion resistance are properties needed in case of surgical tools. Thus, the aim of this research was to study the influence of mechanical abrasion by tumbling and chemical passivation on carbon coatings deposited by reactive magnetron sputtering (RMS) and radio frequency plasma activated chemical vapor deposition (RF PACVD) of X39Cr13 (mainly used for surgical tools) and 316LVM (mainly used for implants). Functional properties, such as roughness, coatings adhesion (scratch test), and wettability were investigated. As a result, DLC coatings applied by magnetron sputtering were found to be the optimum surface treatment in terms of adhesion and wettability properties, being more appropriate for the use of X39Cr13 base than 316LVM for carbon layer deposition.
\end{abstract}

Keywords: DLC coating; wettability; scratch test; martensitic steel; stainless steel

\section{Introduction}

A significant increase in osteosynthesis procedures is associated with the need of adequate surgical instruments. It should be noted that the more complicated a procedure is, the more complex and expensive are the surgical instruments. Therefore, durability and reliability are very important features of those tools. Enhancing the wear resistance of surgical instruments is associated not only with durability and cost of exploitation, but also with the medical aspect of use. This derives from the fact that the operation performed with blunt tools is dangerous for the patient. For example, the drilling process in bone with a blunt instrument generates high temperature that may lead to the thermal necrosis of bone tissue [1,2]. Thus, sufficient durability of tools is a vital factor. In addition, it has a significant influence on the correctness of surgical procedures. Durability of a tool is primarily determined by its geometrical form (adapted to surgery) and selection of the correct metallic materials with mechanical properties that guarantee the transfer of load generated during surgery. In the first step, those properties are selected based on results of numerical analysis (FEM) [3,4]. Tools durability can be improved by enhancing surface layer properties by a surface modification process. In case of surgical tools, information that can be found in the literature is limited because the main area of 
research is the surface treatment of implants [5,6]. For this reason, further research focused on surgical tools is nowadays necessary.

Currently, there are increasing reports of beneficial effects of carbon layers on functional properties of implants and surgical instruments. The use of carbon materials in medical applications is particularly recommended because of the high biocompatibility, the high hardness, wear resistance, low friction coefficient, high thermal conductivity, good optical properties, and the low risk of bacterial colonisation of carbon films [7-9]. Nevertheless, diamond-like carbon (DLC) coatings present adhesion problems previously described by Dalibón et al. [10].

One of the most interesting technology in carbon surface modification is deposition of diamond-like carbon (DLC) coatings [11-13]. This technique includes a film deposition of amorphous carbon and hydrogenated amorphous carbon. In addition, the $\mathrm{sp}^{2}$ and $\mathrm{sp}^{3}$ carbon atoms hybridation plays a significant role on final functional properties [14]. The first attempts to obtain carbon layers with a hydrocarbon dissociation at high temperature were conducted by Aisenberg and Chabot in 1971 [15]. In Poland, the first layer was obtained by reactive pulse plasma method in 1979 by Sokolowski and his associates [16]. In the 1980s, under the direction of Marciniak and Mitura, interdisciplinary research on the use of passive-diamond layers on metal implants had begun $[17,18]$. Since then, continuous attempts were made to improve the technology of carbon coating deposited by both CVD (chemical vapor deposition) and PVD (physical vapor deposition).

Currently, the most commonly used methods of carbon layers deposition are reactive magnetron sputtering (RMS) and radio frequency plasma activated chemical vapor deposition (RF PACVD), utilizing hydrocarbon decomposition in plasma induced in high frequency field. In Poland, these methods were successfully introduced by Mitura and Niedzielski [17,19]. In this study, they selected inter alia: Surgical bone spoons and levers made of Ti-6Al-4V. Tests of tools covered with a carbon layer shown homogeneity over the entire surface. Other studies carried out by other authors reported a critical force $\mathrm{Lc}_{3}$ (complete destruction) in the CoCrMo substrate of $\mathrm{Lc}_{3}=31 \mathrm{~N}$ [20]. The authors [21] conducted a study on DLC coatings applied on a 304L steel base by PVD in $\mathrm{CH}_{4}-\mathrm{H}_{2}$ atmosphere and they found a value of $\mathrm{Lc}_{3}=24 \mathrm{~N}$. That proved the proposed variant of applying DLC by RMS (the composition of the atmosphere was as follows: $80 \% \mathrm{Ar}+10 \% \mathrm{CH}_{4}+10 \% \mathrm{~N}_{2}$ ) for metallic substrate was characterized by higher and more tight adhesion of the layer to the substrate.

On the basis of the previous studies performed by other authors [22,23], good corrosion resistance and abrasion resistance of the prepared samples were found. In previous studies, chemical passivation was identified to be important to increase steels properties [24]. The issue of functional properties improvement of tools by application of proper surface modification was also studied by authors-the group of Prof. Gierzyńska-Dolna and Prof. Nitkiewicz [25]. Among others, they evaluated the influence of nitriding on increased sustainability of surgical tools [26].

If a study focused on surgical tools, after several surgical treatments no losses of tools wear have been found. In most other cases, authors have not even presented any results of the adhesion of coated layers on metallic substrate $[12,13,17-19,27,28]$. Those studies are needed to determine adhesion of analyzed layers, which have been reported to be a problem of DLC coatings in other applications. Furthermore, an important aspect is surface wettability because tools strength and absorption of proteins to the base are highly influenced by the adsorption of moisture by the substrate.

Therefore, the aim of this research was to study the influence of surface roughening by tumbling, chemical passivation, and carbon coating covering using RMS and RF PACVD surface treatments of X39Cr13 (mainly used for surgical tools) and 316LVM (mainly used for implants) steels on roughness, coatings adhesion, and wettability of steels. The final objective was to improve the functional properties of both implants and surgical instruments in order to contribute to increase the safety of surgical procedures and bring tangible economic benefits. 


\section{Materials and Methods}

Research base materials were annealed martensitic stainless steel (X39Cr13) and hardened austenitic stainless steel (316LVM). The normative references used to analyze the chemical composition of the substrates were PN-EN 10088-1:2007 for X39Cr13 and ISO 5832-1:2007 for 316LVM. The normative reference values for the chemical composition of each substrate also with the concentration of the elements obtained in each steel are shown in Table 1 [29].

Table 1. Chemical composition of the analyzed materials.

\begin{tabular}{|c|c|c|c|c|c|c|c|c|c|c|}
\hline \multirow{2}{*}{ Material } & \multirow{2}{*}{ Analysis } & \multicolumn{9}{|c|}{ Mass Concentration of the Elements [\%] } \\
\hline & & $\mathrm{C}$ & Si & Mn & $\mathbf{P}$ & S & $\mathrm{Cr}$ & Mo & $\mathbf{N i}$ & $\mathrm{Fe}$ \\
\hline \multirow{2}{*}{ X39Cr13 } & $\begin{array}{l}\text { normative } \\
\text { reference }\end{array}$ & $\begin{array}{c}0.36- \\
0.42\end{array}$ & $\begin{array}{c}1.0 \\
\max \end{array}$ & $\begin{array}{l}1.0 \\
\max \end{array}$ & $\begin{array}{l}0.045 \\
\max .\end{array}$ & $\begin{array}{l}0.015 \\
\max .\end{array}$ & $\begin{array}{l}12.5- \\
14.5\end{array}$ & - & - & \\
\hline & sample & 0.38 & 0.75 & 0.85 & 0.034 & 0.011 & 13.2 & - & - & bal. \\
\hline \multirow{3}{*}{ 316LVM } & normative & 0.030 & 1.0 & 2.0 & 0.025 & 0.01 & & $2.25-$ & $13.0-$ & \\
\hline & reference & $\max$ & $\max$ & $\max$ & $\max$ & $\max$. & & 3.0 & 15.0 & \\
\hline & sample & 0.022 & 0.59 & 1.67 & 0.015 & 0.001 & 17.5 & 2.75 & 14.25 & bal. \\
\hline
\end{tabular}

X39Cr13 steel samples were heat-treated (quenching and low tempering). Afterwards, both martensitic and austenitic steels were prepared in the form of disks with a diameter $\mathrm{d}=14 \mathrm{~mm}$ and a thickness of $\mathrm{h}=1.5 \mathrm{~mm}$ cut from the sheet using laser technology on the Trumpf Lasercell 1005 (Kistner Company, Berlin, Germany) device. Subsequently, the following surface treatments were applied: 1) Tumbling in an aqueous suspension with a silica part of $1 / 3$ of the total barrel load (by using a K14 barrel tumbler of Kramer Industries Inc. for $\mathrm{t}=11 \mathrm{~h}$ at $28 \mathrm{rpm}$ ), 2) chemical passivation in $40 \% \mathrm{HNO}_{3}$ solution $\left(\mathrm{T}=60 \pm 1^{\circ} \mathrm{C} ; \mathrm{t}=1 \mathrm{~h}\right.$ ) and 3 ) deposition of DLC coating by RMS or RF PACVD. These methods were implemented in atmospheres of different chemical composition. In the case of the magnetron method the composition of the atmosphere was as follows: $80 \% \mathrm{Ar}+10 \% \mathrm{CH}_{4}+10 \% \mathrm{~N}_{2}$, in turn, for the RF PACVD method: $80 \% \mathrm{CH}_{4}+20 \% \mathrm{~N}_{2}$.

The thickness of the DLC layer was determined by interferometry. In this method, once the interference signals appear at the surfaces of films, a special algorithm is used so that the film thickness can be extracted from the interferogram. This test was performed by Taylor Hobson enterprise with the samples that we sent to them. DLC layer was also analyzed in order to obtain its hydrogen content by elastic recoil detection analysis (ERDA). Once the hydrogen content was known, the expression proposed by Bewilogua [30] was applied in order to obtain the $\mathrm{Xsp}^{3} / \mathrm{Xsp}^{2}$ quotient in both deposited layers.

Surface roughness Ra tests were carried out on the samples in each successive step of surface treatment: Tumbling, passivation, and deposition of the carbon layers by RF PACVD and RMS methods. The study was performed using a profilometer Surtronic 3 + Taylor Hobson.

The adhesion and mechanical failure properties were studied by a scratch test. In this procedure, a microcombi tester integrated in the CSM platform was used, as previously described [31]. During these tests, the substrate was scratched by a diamond cone Rockwell penetrator. The normal force was programmed to increase $10 \mathrm{~N} / \mathrm{s}$ from the value of 0.03 to $50 \mathrm{~N}$. The penetrator speed was adjusted to $10 \mathrm{~mm} / \mathrm{min}$ and the test was considered to be finished when a scratch length of $3 \mathrm{~mm}$ was reached. This procedure was repeated 5 times on each sample. Scratch tests were programmed on substrates that were previously covered with a carbon layer by using RMS and RF PACVD. The main output obtained by the scratch tests was the critical applied force. The friction force $\left(\mathrm{F}_{t}\right)$ can be defined as such that is along the contact surface and opposite in direction of any applied force. The value of the friction force can be obtained by Equation (1):

$$
F_{t}=\mu \cdot F_{N}
$$

where $\mu$ is the friction coefficient and $F_{N}$ is the normal load acting between the two objects. The friction force equals the applied force in absolute value until the sample cracks [32]. The applied force at this 
point is called the critical applied force and it is defined as the smallest normal force which caused the adhesion to the substrate to be lost. Afterwards, the object begins to move the layer delaminates and, finally, it breaks completely. For the sake of precision, the critical force value was obtained by recording the friction coefficient, the friction force, and the acoustic emission (AE) signals in all measurements. The AE signal is produced by stick-slip motion of two materials in contact. Thus, the maximum $\mathrm{AE}$ signal was associated to the layer crack, while the lowest value was due to the complete breakdown (and, consequently, the material separation). AE signals were recorded and analyzed by digital processing AE analyzer DAKEL-XEDO. In order to verify the adhesion lost, a microscopic observation of the substrate was performed.

Finally, wettability tests were performed by the procedure developed by Basiaga et al. [33]. Wettability is a property that allows to measure the degree of absorption and aggregation of the material. This is connected with the physical phenomena occurring on its surface, mainly the surface energy, the size of which determinates rate and extent of aggregation factors such as bacterial plaque, hydrophobicity, or hydrophilicity of the material. The degree and time in which the material absorbs moisture, has a large influence on the strength of implants and protection of patients against the risk of inflammation [33]. It has also been pointed out that wettability influence greatly the protein adsorption and subsequent confirmation, playing a significant role on the biocompatibility of the material [34]. Tests were performed for each surface modification previously explained. Surface was prepared by cleaning in an ultrasonic Bandelin Sonorex Digitec washer and drying. Finally, the samples were placed on a table under a Surftens Universtal goniometer dispenser. Before testing, calibration was performed using the pertinent markers. Afterwards, 5 drops of distilled water of $2 \mu \mathrm{L}$ volume each were deposited on the surface of each sample. The measurement of the angle in the goniometer was carried out $20 \mathrm{~s}$ after dispensing the drop on the sample. This procedure lasted $60 \mathrm{~s}$ and it was recorded every $1 \mathrm{~s}$. At last, the values of the wetting angles were expressed as mean values with the corresponding standard deviation.

For the sake of comparison, statistical analyses were performed using SPSS Statistics software (v.26 for Windows, IBM Corporation, New York, NY, USA) for surface roughness, scratch tests, and wettability tests results. The mean values, along with the standard deviation, were studied by analysis of variance (ANOVA) followed by Tukey's test. For the surface roughness and wettability results, also the different treatments (tumbling, tumbling + passivation, carbon layer (RMS) and carbon layer (RF PACVD)) were statistically compared. For all statistical tests, significance was predetermined at $\mathrm{p}<0.05$.

\section{Results and Discussion}

\subsection{Characterization of DLC Layer}

The results of DLC layer characterization for both substrates are shown in Table 2.

Table 2. Results of diamond-like carbon (DLC) layer characterization.

\begin{tabular}{ccccc}
\hline Material & $\begin{array}{c}\text { Surface } \\
\text { Treatment }\end{array}$ & $\begin{array}{c}\text { Layer } \\
\text { Thickness }[\mu \mathrm{m}]\end{array}$ & $\begin{array}{c}\text { Hydrogen } \\
\text { Content }[\%]\end{array}$ & Xsp $^{\mathbf{3}} / \mathbf{X s p}^{2}$ \\
\hline \multirow{2}{*}{ X39Cr13 } & RMS & $1.3 \pm 0.1$ & $17.1 \pm 0.1$ & $0.25 \pm 0.03$ \\
& RF PACVD & $1.4 \pm 0.1$ & $39.2 \pm 0.2$ & $0.47 \pm 0.04$ \\
\hline \multirow{2}{*}{ 316LVM } & RMS & $1.4 \pm 0.1$ & $16.3 \pm 0.1$ & $0.21 \pm 0.03$ \\
& RF PACVD & $1.5 \pm 0.1$ & $38.6 \pm 0.2$ & $0.44 \pm 0.04$ \\
\hline
\end{tabular}

* Values expressed as mean \pm standard deviation.

From the data of Table 2, it can be concluded that the thickness of the DLC layer was similar on each substrate. In contrast, the hydrogen content of the DLC layer was very dependent on the surface treatment applied to the metals, as also observed by Muguruma [35] and Bewilogua [30]. In this sense, 
RF PACVD showed more than double hydrogen content in DLC layer than that produced by RMS. It can be also observed that DLC layer produced by RF PACVD reveals a higher $\mathrm{Xsp} / \mathrm{Xsp}^{2}$ quotient than that obtained with RMS, probably due to the higher hydrogen content of the atmosphere in which RF PACVD was applied [34].

\subsection{Roughness Measurements}

The results of the roughness measurements are summarized in Table 3. The mean surface roughness after tumbling was equal to $\mathrm{Ra}=0.44 \mu \mathrm{m}$ for $\mathrm{X} 39 \mathrm{Cr} 13$ steel samples and $0.46 \mu \mathrm{m}$ for 316LVM samples. For the sake of comparison between the two substrates, $\mathrm{p}$-values of ANOVA tests are also included.

Table 3. Results of comparative surface roughness, $R_{a}[\mu \mathrm{m}]$, of the analyzed materials.

\begin{tabular}{cccc}
\hline Surface Treatment & X39Cr13 & 316LVM & p-Value \\
\hline Tumbling & $0.44 \pm 0.04$ & $0.46 \pm 0.05$ & 0.098 \\
Tumbling + passivation & $0.42 \pm 0.05$ & $0.41 \pm 0.04$ & 0.077 \\
Carbon layer (RMS) & $0.19 \pm 0.03$ & $0.21 \pm 0.02$ & 0.021 \\
Carbon layer (RF PACVD) & $0.33 \pm 0.04$ & $0.37 \pm 0.03$ & 0.002 \\
\hline \multicolumn{4}{c}{ *Values expressed as mean \pm standard deviation. }
\end{tabular}

From the results shown in Table 3, it can be concluded that surface roughness was not significantly different between the both substrates when tumbling and tumbling + passivation were applied ( $p$-value $>0.05$ ). However, these values were significantly different between X39Cr13 and 316LVM when the carbon layer was deposited. In order to compare the different steps of the surface treatment, Table 4 shows the statistical analysis of the surface roughness for the X39Cr13 and 316LVM.

Table 4. Statistical analysis (p-values) of the surface roughness for X39Cr13 // 316LVM.

\begin{tabular}{ccccc}
\hline Surface Treatment & Tumbling & $\begin{array}{c}\text { Tumbling + } \\
\text { Passivation }\end{array}$ & $\begin{array}{c}\text { Carbon Layer } \\
\text { (RMS) }\end{array}$ & $\begin{array}{c}\text { Carbon Layer } \\
\text { (RF PACVD) }\end{array}$ \\
\hline Tumbling & - & $0.069 / / 0.003$ & $0.001 / / 0.002$ & $0.018 / / 0.021$ \\
$\begin{array}{c}\text { Tumbling }+ \\
\text { passivation }\end{array}$ & - & - & $0.004 / / 0.006$ & $0.024 / / 0.026$ \\
Carbon layer (RMS) & - & - & - & $0.039 / / 0.033$ \\
\hline
\end{tabular}

As shown in Table 4, surface roughness was not significantly affected by chemical passivation for X39Cr13 while the opposite trend was observed for 316LVM. Although the X39Cr13 result differs from some published studies [10] that reported an increase in roughness values after passivation, they could be explained by the probably lower surface defects in the steel substrate.

However, deposition of carbon layers by RMS and by RF PACVD after passivation produced a significantly reduction in the surface roughness. On the one hand, for carbon layers deposited by means of RMS, the surface roughness of both X39Cr13 and 316LVM samples were equal to Ra $=0.19 \mu \mathrm{m}$ and $\mathrm{Ra}=0.21 \mu \mathrm{m}$, respectively. On the other hand, for carbon layers deposited by the RF PACVD method the surface roughness decreased to the value of $\mathrm{Ra}=0.33 \mu \mathrm{m}$ for X39Cr13 substrate and $\mathrm{Ra}=0.37 \mu \mathrm{m}$ for 316LVM substrate. As a result, the RSM deposition method was found to be the best carbon coating procedure by judged by the surface roughness evaluation. This finding was in agreement with expectations because the low $\mathrm{Xsp}^{3} / \mathrm{Xsp}^{2}$ fraction is frequently associated with a lower surface roughness as described by Narayan and Ma et al. [34,36].

\subsection{Adhesion Tests}

An example of the adhesion test of X39Cr13 substrate is presented in Figure 1 (RMS) and Figure 2 (RF PACVD). As revealed in Figure 1, the three layer failure types can be observed in coatings applied 
by RMS: Cracking, delamination, and complete breakup. The acoustic emission peak can be associated to the material separation (cracking). If the test continues, a local minimum of the acoustic emission line is observed and associated with the complete breakdown of the carbon layer. It can also be observed (Figure 2) that the carbon layer adhesion was really poor when RF PACVD was used as the complete layer breakdown occurred at a load force of only $3.94 \mathrm{~N}$.

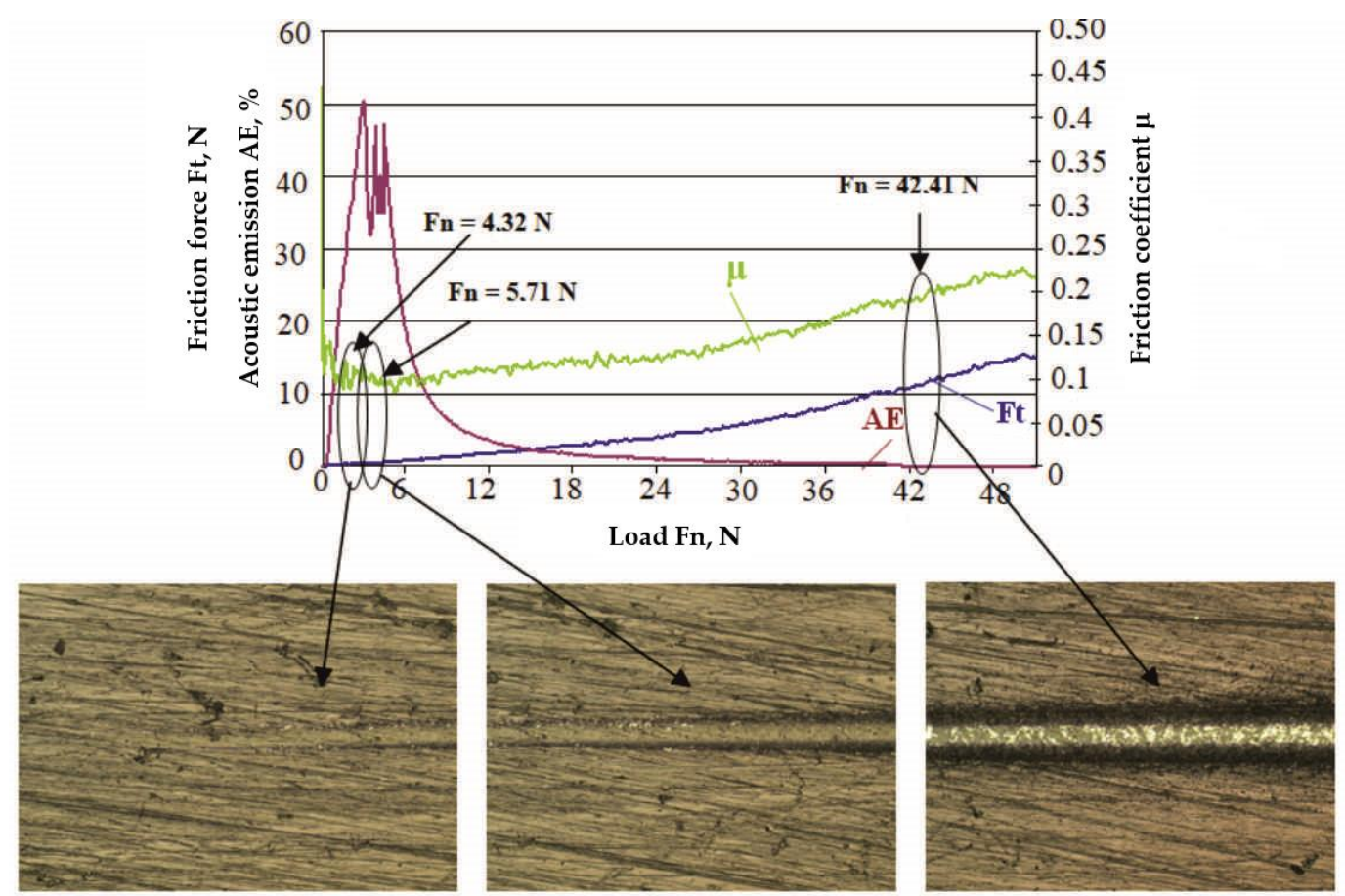

Figure 1. Example scratch tests on the carbon layer deposited by reactive magnetron sputtering (RMS) on the X39Cr13 substrate.

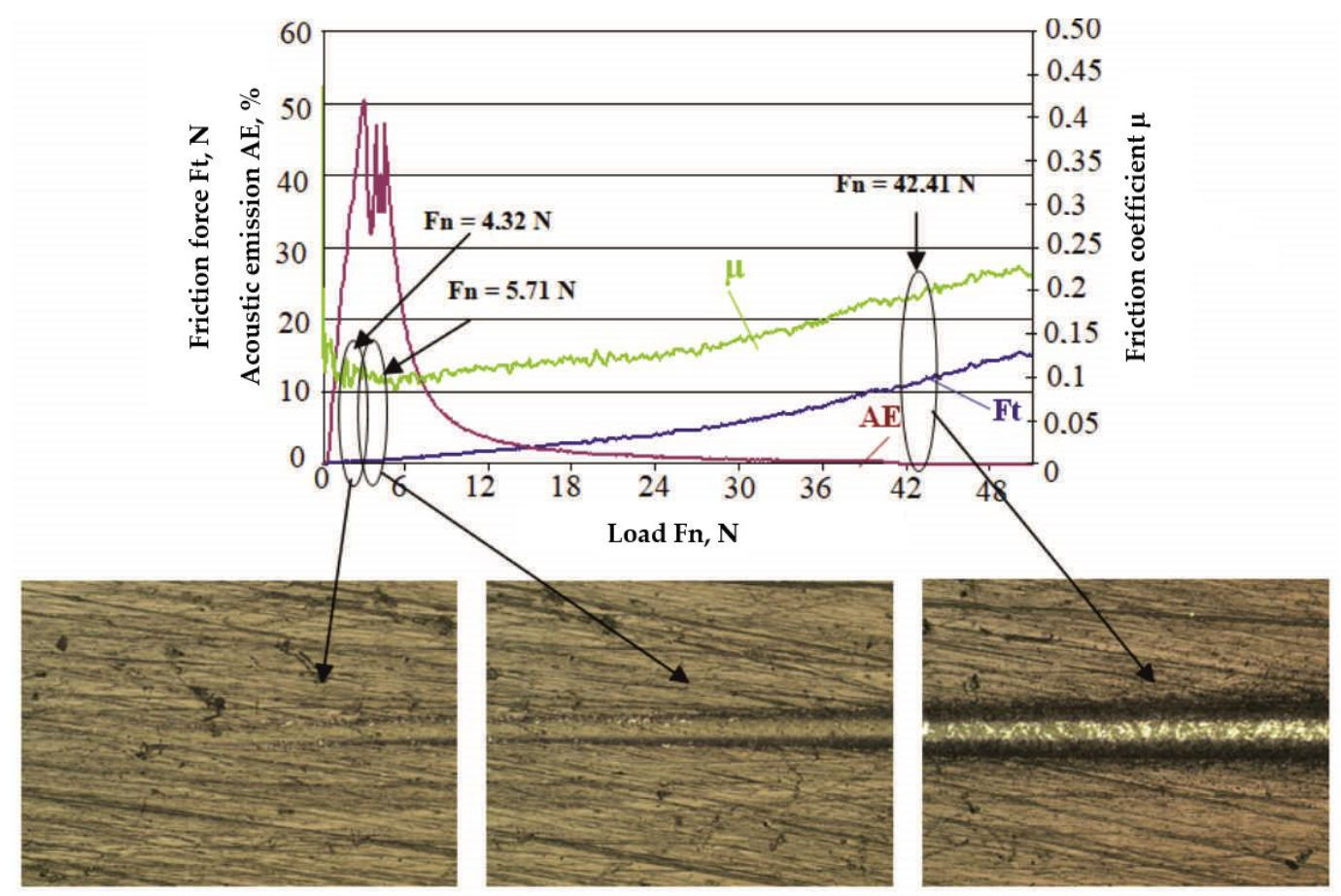

Figure 2. Adhesion of the carbon layer deposited by radio frequency plasma activated chemical vapor deposition (RF PACVD) on the X39Cr13 substrate. 
The results of the adhesion tests for both X39Cr13 and 316LVM steels are listed in Table 5. Table 6 shows the ANOVA results of the different deposition methods used.

Table 5. Results of comparative adhesion of the carbon layer, indenter load $F_{n}[N]$, to the substrates.

\begin{tabular}{ccccc}
\hline Surface Treatment & Failure of the Layer & X39Cr13 & 316LVM & p-Value \\
\hline Tumbling + passivation + & cracking $\left(\mathrm{Lc}_{1}\right)$ & $4.32 \pm 0.36$ & $3.11 \pm 0.46$ & 0.032 \\
carbon layer by RMS & $\begin{array}{c}\text { delamination }\left(\mathrm{Lc}_{2}\right) \\
\text { complete breakdown }\left(\mathrm{Lc}_{3}\right)\end{array}$ & $5.71 \pm 0.47$ & $3.97 \pm 0.65$ & 0.041 \\
& complete breakdown $\left(\mathrm{Lc}_{3}\right)$ & $3.94 \pm 0.78$ & $3.28 \pm 0.90$ & 0.126 \\
\hline $\begin{array}{c}\text { Tumbling + passivation + } \\
\text { carbon layer by RF PACVD }\end{array}$ & * Values expressed as mean \pm standard deviation. & & \\
\hline
\end{tabular}

Table 6. Statistical analysis (p-value) of the adhesion of the carbon layer for X39Cr13 // 316LVM.

\begin{tabular}{cc}
\hline Surface Treatment & $\begin{array}{c}\text { Tumbling + Passivation }+ \\
\text { Carbon Layer by RF PACVD }\end{array}$ \\
\hline $\begin{array}{c}\text { Tumbling + passivation }+ \\
\text { carbon layer by RMS }\end{array}$ & $<0.001 / /<0.001$ \\
\hline
\end{tabular}

RMS samples showed the best layer adhesion, with a layer delamination produced at a critical force value of $\mathrm{Lc}_{3}=45.73 \mathrm{~N}$ for the $\mathrm{X} 39 \mathrm{Cr} 13$ substrate and $\mathrm{Lc}_{3}=42.41 \mathrm{~N}$ for the 316LVM substrate. In turn, in the case of layers deposited by RF PACVD, the value of the critical force was much smaller and was equal to $\mathrm{Lc}_{3}=3.94 \mathrm{~N}$ for the $\mathrm{X} 39 \mathrm{Cr} 13$ substrate and $\mathrm{Lc}_{3}=3.28 \mathrm{~N}$ for the $316 \mathrm{LVM}$ substrate.

From the scratch test results in Table 5, it can be concluded that the carbon layers adhered significantly different to the X39Cr13 and 316LVM substrates when RMS was used. It is also true that no significant differences are found between both substrates at carbon layer complete break. However, the differences observed when the layer cracks and delaminates are enough to support the previous conclusion. On the other hand, when RF PACVD was used, no significant differences were observed between the adhesion of the carbon layer in both substrates.

It can also be observed that 316LVM produced a layer failure at lower loads at crack and delamination of the carbon layer, possibly related to the negative tensiles between the passivation layer and the carbon coating due to the higher roughness of the 316LVM steel.

Finally, Table 6 reveals that the adhesion of the carbon layer was significantly different when RMS or RF PACVD were applied. The data shown in Table 5, confirm that the RSM deposition method was the better carbon coating procedure in terms of adhesion of the carbon layer.

\subsection{Wettability Results}

An example of the contact angle measurement of wettability tests for both substrates is shown in Figure 3.
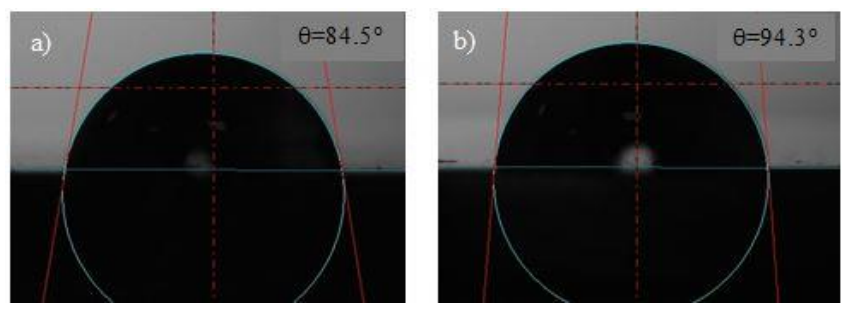

Figure 3. Contact angle measurement, carbon layer (RMS): (a) X39Cr13 steel, (b) 316LVM steel.

Table 7 presents the contact angle results for both substrates after each step of surface treatment performed. From results of Table 7 , tumbling and tumbling + passivation treatments did not produce 
a significant contact angle difference. However, the deposition of the carbon layer on X39Cr13 and 316LVM substrates (by RMS or RF PACVD) caused a significant difference in wettability on both materials.

Table 7. Results of contact angle $\theta\left[{ }^{\circ}\right]$ measurements of the analyzed materials.

\begin{tabular}{cccc}
\hline Surface Treatment & X39Cr13 & 316LVM & p-Value \\
\hline Tumbling & $102.3 \pm 2.8$ & $100.0 \pm 2.1$ & 0.102 \\
Tumbling + passivation & $100.2 \pm 2.3$ & $99.2 \pm 1.8$ & 0.183 \\
Carbon layer (RMS) & $84.5 \pm 1.6$ & $94.3 \pm 2.6$ & 0.017 \\
Carbon layer (RF PACVD) & $94.3 \pm 3.0$ & $99.5 \pm 2.9$ & 0.039 \\
\hline
\end{tabular}

${ }^{*}$ Values expressed as mean \pm standard deviation.

For the sake of comparison between the different surface treatments steps, Table 8 presents the statistical analysis of the contact angle measurements by each step of the procedure.

Table 8. Statistical analysis (p-values) of the contact angle measurements for X39Cr13 // 316LVM.

\begin{tabular}{ccccc}
\hline Surface Treatment & Tumbling & $\begin{array}{l}\text { Tumbling + } \\
\text { Passivation }\end{array}$ & $\begin{array}{c}\text { Carbon Layer } \\
\text { (RMS) }\end{array}$ & $\begin{array}{c}\text { Carbon Layer } \\
\text { (RF PACVD) }\end{array}$ \\
\hline $\begin{array}{c}\text { Tumbling } \\
\text { Tumbling + } \\
\text { passivation }\end{array}$ & - & $0.108 / / 0.190$ & $0.021 / / 0.037$ & $0.041 / / 0.348$ \\
Carbon layer (RMS) & - & - & $0.014 / / 0.032$ & $0.019 / / 0.399$ \\
\hline
\end{tabular}

From Table 8 (in conjunction with Table 7), it can be concluded that chemical passivation did not caused a significant difference in the contact angle on both substrates. Another important finding was that deposition of the carbon layer by RMS caused a significant contact angle reduction, regardless of the substrate material. In this case, the values of the contact angle were $\theta=84.5^{\circ}$ for the X39Cr13 and $\theta$ $=94.3^{\circ}$ for the 316LVM, respectively. As a result, carbon layer deposition by RMS on both substrates enhanced the material wettability. However, considering RF PACVD, only carbon deposition on X39Cr13 produced a significant increase in wettability (while 316LVM presented a similar behavior in this field). Finally, both RMS and RF PACVD methods were found to be significantly different in the wettability of the carbon layer. In conclusion, lower contact angles were obtained associated with the lower surface roughness of steels except in the tumbling case, probably due to the different composition of substrates. In this sense, Liu et al. showed that phosphorous [34,37] content could improve metals wettability. As X39Cr13 presents a higher phosphorous content than 316LVM, it can be expected a lower contact angle on X39Cr13 substrate.

Lee et al. [38] identified the surface morphology and chemistry to be the most influencing factors in substrates wetting behavior. In the actual research, contact angles values were in accord with literature. The results of authors' research revealed that the most advantageous surface layer is DLC applied by magnetron method, that was confirmed by previous results [39], whose authors obtained comparable values of $\theta=82.4^{\circ}$ for surface layer applied to a $100 \mathrm{Cr} 6$ steel base.

\section{Conclusions}

Appropriate surface treatment has a prospective significance and contributed to the development of technological conditions to deposit carbon layers on medical devices used in bone surgery to improve their functional properties. The results of the study show clearly that the proposed surface treatment that includes: Tumbling, chemical passivation, and deposition of DLC layers by reactive magnetron sputtering (RMS) revealed the best adhesion to the base material and wettability being, as a whole, a more positive X39Cr13 substrate than the 316LVM substrate. Therefore, studies on adhesion of coating layers as well as their wettability can be a valuable addition to the database of mechanical and physicochemical properties of protective surface layers. 
Author Contributions: Conceptualization, R.L. and A.B.-S.; methodology, R.L., M.M., and C.F.; software, A.C.; investigation, R.L. and A.C.; resources, M.M.; data curation, C.F.; writing-original draft preparation, M.M., C.F., and A.C.; writing-review and editing, R.L. and A.B.-S,; supervision, R.L.

Funding: This research received no external funding.

Conflicts of Interest: The authors declare no conflict of interest.

\section{References}

1. Basiaga, M.; Paszenda, Z.; Szewczenko, J.; Kaczmarek, M. Influence of surgical drills wear on thermal process generated in bones. Acta Bioeng. Biomech. 2013, 15, 21-29.

2. Kiel, M.; Marciniak, J.; Basiaga, M.; Szewczenko, J. Numerical analysis of spine stabilizers on lumbar part of spine. Adv. Intell. Soft Comp. 2010, 69, 447-456.

3. Pochrzast, M.; Marciniak, J.; Kaczmarek, M. Biomechanical analysis of limited-contact plate used for osteosynthesis. Acta Bioeng. Biomech. 2014, 16, 99-105. [PubMed]

4. Marciniak, J.; Szewczenko, J.; Walke, W.; Basiaga, M.; Kiel, M.; Manka, I. Biomechanical analysis of lumbar spine stabilization by means of transpedicular stabilizer. Adv. Intell. Soft Comp. 2008, 47, 529-536.

5. Walke, W.; Przondziono, J. Influence of hardening and surface modification of endourological wires on corrosion resistance. Acta Bioeng. Biomech. 2012, 14, 93-99. [PubMed]

6. Walke, W.; Paszenda, Z.; Basiaga, M.; Karasinski, P.; Kaczmarek, M. EIS study of SiO2 Oxide Film on 316L stainless steel for cardiac implants. Adv. Intell. Soft Comp. 2014, 284, 403-410.

7. Hauert, R.; Thorwarth, K.; Thorwarth, G. An overview on diamond-like carbon coatings in medical applications. Surf. Coatings Technol. 2013, 233, 119-130. [CrossRef]

8. Zhang, T.F.; Deng, Q.Y.; Liu, B.; Wu, B.J.; Jing, F.J.; Leng, Y.X.; Huang, N. Wear and corrosion properties of diamond like carbon (DLC) coating on stainless steel, CoCrMo and Ti6Al4V substrates. Surf. Coat. Technol. 2015, 273, 12-19. [CrossRef]

9. Zhang, C.; Fujii, M. Influence of Wettability and Mechanical Properties on Tribological Performance of DLC Coatings under Water Lubrication. J. Surf. Eng. Mater. Adv. Technol. 2015, 5, 110-123. [CrossRef]

10. Dalibon, E.L.; Escalada, L.; Simison, S.; Forsichc, C.; Heimc, D.; Brühla, S.P. Mechanical and corrosion behavior of thick and soft DLC coatings. Surf. Coat. Tech. 2016, 312, 101-109. [CrossRef]

11. Kovaci, H.; Baran, O.; Bayrak, O.; Yetin, A.F.; Çelik, A. Influence of plasma nitriding treatment on the adhesion of DLC films deposited on AISI 4140 steel by PVD magnetron sputtering. J. Adhes. Sci. Technol. 2017, 31, 2015-2027. [CrossRef]

12. Allen, M.; Myer, B.; Rushton, N. In vitro and in vivo investigations into the biocompatibility of DLC coatings for orthopedic applications. J. Biomed. Mater. Res. B 2007, 58, 319-328. [CrossRef]

13. Grabarczyk, J.; Kotela, I. Plasma modification of medical implants by carbon coatings depositions. J. Achiev. Mater. Manuf. Eng. 2009, 37, 277-281.

14. Gotzmann, G.; Beckmann, J.; Wetzel, C.; Scholz, B.; Herrmann, U.; Neunzehn, J. Electron-beam modification of DLC coatings for biomedical applications. Surf. Coat. Tech. 2017, 311, 248-256. [CrossRef]

15. Aisenberg, S.; Chabot, R. Ion-Beam Deposition of Thin Films of Diamondlike Carbon. J. Appl. Phys. 1971, 42, 2953. [CrossRef]

16. Sokołowski, M.; Sokołowska, A.; Gokieli, B.; Michalski, A.; Rusek, A.; Romanowski, Z. Reactive pulse plasma crystallization of diamond and diamond-like carbon. J. Cryst. Growth 1979, 47, 421-426. [CrossRef]

17. Mitura, E.; Mitura, S.; Niedzielski, P.; Marciniak, J. Diamond-like carbon coatings for biomedical applications. Diam. Relat. Mater. 1994, 3, 896-898. [CrossRef]

18. Niedzielski, P.; Mitura, S.; Paszenda, Z.; Marciniak, J. Proceedings on carbon coatings. In Proceedings of the 8th International Science Conference of Achievements in Mechanical and Materials Engineering, Gliwice, Poland, 22-25 October 1999.

19. Mitura, S.; Mitura, E.; Mitura, A. Manufacture of amorphous carbon layers by rf dense plasma CVD. Diam. Relat. Mater. 1995, 4, 302-303. [CrossRef]

20. Zaidi, H.; Djamai, A.; Chin, K.J.; Mathia, T. Characterisation of DLC coating adherence by scratch testing. Tribol. Int. 2006, 36, 124-128. [CrossRef]

21. Madej, M.; Ozimina, D. Ocena właściwości powłok DLC stosowanych w układach biotribologicznych (Evaluation of the properties of DLC coatings used in biotribological systems). Tribologia 2009, 3, 105-114. 
22. Basiaga, M.; Paszenda, Z.; Walke, W. Badania własności elektrochemicznych warstw węlowych stosowanych na wyrobach medycznych (Studies on the electrochemical properties of carbon layers used on medical devices). Prz. Elektrotech. 2011, 87, 12-15.

23. Kiel-Jamrozik, M.; Paszenda, Z.; Jaglarz, J. Topografia i grubość warstw węglowych wytworzonych na stali martenzytycznej przeznaczonej na narzedzia chirurgiczne (Topography and thickness of carbon layers produced on martensitic steel for surgical tools). Prz. Elektrotech. 2013, 12, 317-320.

24. Biel-Golaska, M.; Kalemba, I. Analiza zużycia narzędzi medycznych pokrytych powłokami (Analysis of the wear of medical tools covered with coatings). Odlew. - Nauk. i Prakt. 2006, 5, 17-26.

25. Gierzynska-Dolna, M. Biotribologia; Czestochowskiej, W.P., Ed.; Wydawnictwo. Politechniki Częstochowskiej: Częstochowa, Poland, 2002.

26. Gwozdzik, M.; Nitkiewicz, Z. Wear resistance of steel designed for surgical instruments after heat and surface treatments. Arch. Met. Mater. 2009, 54, 241-246.

27. Niedzielski, P. Warstwy węglowe na narzędziach skrawających (Carbon layers on cutting tools). Zesz. Nauk. 2005, 23, 955-962.

28. Basiaga, M.; Paszenda, Z.; Walke, W.; Karasinski, P.; Marciniak, J. Electrochemical impedance spectroscopy and corrosion resistance of $\mathrm{SiO} 2$ coated cpTi and Ti-6Al-7Nb alloy. Adv. Intell. Soft Comp. 2014, 284, 411-420.

29. Pietça, E.; Badura, P.; Kawa, J.; Wieclawek, W. Carbon coatings advances for biomedicine applications. In Proceedings of the Information technologies in Medicine, Kamień Śląski, Poland, 20-22 June 2016; p. 407.

30. Bewilogua, K.; Hofmann, D. History of diamond-like carbon films-From first experiments to worldwide applications. Surf. Coatings Technol. 2014, 242, 214-225. [CrossRef]

31. DIN-EN-ISO 20502. Determination of Adhesion of Ceramic Coatings by Scratch Testing; Deutsches Institut fur Normung E.V. (DIN): Berlin, Germany, 2016; pp. 1-37.

32. Prevorovsky, D.; Prevorovsky, Z.; Asserin, J.; Varchon, D. Acoustic emission characteristics of surface friction in bio-medical application. J. Acoust. Emiss. 2002, 20, 285-291.

33. Basiaga, M.; Jendrus, R.; Walke, W. Influence of surface modification on properties of stainless steel used for implants. Arch. Met. Mater. 2015, 60, 2965-2969. [CrossRef]

34. Diamond Based Materials For Biomedical Applications; Narayan, R. (Ed.) Woodhead Publishing: Cambridge, UK, 2013.

35. Muguruma, T.; Iijima, M.; Kawaguchi, M.; Mizoguchi, I. Effects of $\mathrm{sp}^{2} / \mathrm{sp}^{3}$ ratio and hydrogen content on in vitro bending and frictional performance of DLC-coated orthodontic stainless steels. Coatings 2018, 8, 199. [CrossRef]

36. Ma, W.J.; Ruys, A.J.; Mason, R.S. DLC coatings: effects of physical and chemical properties on biological response. Biomaterials 2007, 28, 1620-1628. [CrossRef] [PubMed]

37. Liu, A.; Zhu, J.; Liu, M. Platelet adhesion on phosphorus-incorporated tetrahedral amorphous carbon films. Appl. Surf. Sci. 2008, 255, 279-281. [CrossRef]

38. Lee, W.H.; Loo, C.Y.; Rohanizadeh, R. A review of chemical surface modification of bioceramics: effects on protein adsorption and cellular response. Colloids Surf., B 2014, 122, 823-834. [CrossRef] [PubMed]

39. Kalin, M.; Polajnar, M. The importance and correlations of surface energy, surfacetension, contact angle and spreading. Appl. Surf. Sci. 2014, 293, 97-108. [CrossRef]

(C) 2019 by the authors. Licensee MDPI, Basel, Switzerland. This article is an open access article distributed under the terms and conditions of the Creative Commons Attribution (CC BY) license (http://creativecommons.org/licenses/by/4.0/). 